\title{
Improved Procedure for Electro-Spinning and Carbonisation of Neat Solvent-Fractionated Softwood Kraft Lignin
}

\author{
Inam Khan \\ University of Birmingham \\ Bongkot Hararak \\ University of Birmingham \\ Gerard Franklyn Fernando ( $\nabla$ g.fernando@bham.ac.uk) \\ University of Birmingham
}

\author{
Research Article \\ Keywords: Lignin, solvent fractionation, electro-spinning, DMSO, BioChoice®, carbon fibre, lignin blends \\ Posted Date: February 16th, 2021 \\ DOI: https://doi.org/10.21203/rs.3.rs-195377/v1 \\ License: (c) (i) This work is licensed under a Creative Commons Attribution 4.0 International License. Read Full License
}

Version of Record: A version of this preprint was published at Scientific Reports on August 10th, 2021. See the published version at https://doi.org/10.1038/s41598-021-95352-5. 


\section{Abstract}

In general, the electro-spinning of lignin requires it to be functionalised and/or blended with synthetic or natural polymers. This paper reports on the use of solvent fractionated lignin-lignin blend to electro-spin BioChoice ${ }^{\circledR}$ softwood Kraft lignin. The blend consisted of acetone-soluble and ethanol-soluble lignin in a binary solvent of acetone and DMSO. Solvent fractionation was used to purify lignin where the ash content was reduced in the soluble lignin fractions from $1.24 \%$ to $\sim 0.1 \%$. The corresponding value for conventional acidwashing in sulphuric acid was $0.34 \%$. A custom-made electro-spinning apparatus was used to produce the nano-fibres. Heat treatment procedures were developed for drying the electro-spun fibres prior to oxidation and carbonisation; this was done to prevent fibre fusion. The lignin fibres were oxidised at $250 \otimes \mathrm{C}$, carbonised at 1000هC and 1500囚C. The cross-section of the fibres was circular and they were observed to be void-free. The longitudinal sections showed that the fibres were not fused. Thus, this procedure demonstrated that solvent fractionated lignin can be electro-spun without using plasticisers or polymer blends using common laboratory solvents and subsequently carbonised to produce carbon fibres with a circular cross-section.

\section{Introduction}

Over the past decade, the use of naturally occurring biomaterials such as lignin and cellulose as an alternative precursor to polyacrylonitrile (PAN) for the production of carbon fibres has been studied extensively. ${ }^{1-5}$ PAN continues to be the primary precursor for the production of carbon fibres. However, PAN is derived from petroleum and it is not a sustainable precursor in the long-term ${ }^{6,7}$. There is significant ongoing global interest in identifying and using sustainable, low-cost and environmentally-friendly precursors for the production of carbonised fibres ${ }^{8-10}$. Due to its chemical structure, abundance and high carbon content, lignin has been considered to be a potential low-cost alternative precursor for the production of carbon fibres ${ }^{7,11-13}$. Approximately 50 million tonnes of lignin is produced per year by the paper and pulp industry ${ }^{8,14}$. However, only $1-2 \%$ of the lignin produced is used in other industries whilst the rest is burned as fuel for energy generation ${ }^{14,15}$.

Generally, lignin is initially purified by washing it with an acid to reduce the carbohydrate content, inorganic impurities and other contaminants $^{16-19}$. These impurities effect the ability of the lignin/solvent solution to be spun into fibres ${ }^{16,20,21}$. The acid-washed lignin is fractionated, chemically modified or blended with co-polymers to aid fibre spinning and to improve the desired properties ${ }^{22-25}$. The source, type of lignin and the extraction procedures used influence its processability during fibre spinning ${ }^{2,26}$. Finally, the fibres are subjected to prolonged heat-treatment to carbonise them.

Electro-spinning is a cost-effective method to produce nano-fibre preforms that can subsequently be carbonised ${ }^{27-30}$. The applications of carbonised lignin fibres include nano-composites ${ }^{31}$, tissue scaffolds for biomedical applications ${ }^{32}$, sensors ${ }^{33}$, filtration technologies ${ }^{21}$, lithium ion batteries ${ }^{34}$, sodium ion batteries ${ }^{35}$, fuels cells ${ }^{36}$, double layer capacitors ${ }^{37}$ and dye-sensitized solar cells for energy storage and batteries related applications ${ }^{38}$.

Polymers such as polyethylene oxide, polyvinyl alcohol, polyacrylonitrile and cellulose have been blended with lignin ${ }^{25,38-43}$. One of the reasons for blending lignin with other polymers is to improve its viscoelastic properties which in turn aids electro-spinning ${ }^{44-46}$. The difficulty in electro-spinning lignin is attributed to its molecular weight distribution, cross-linking during processing and intermolecular interaction within the lignin framework. Blending lignin with polymers or plasticisers is thought to facilitate polymer entanglement by disrupting the intermolecular interactions and altering its viscoelastic properties which in turn is said to improve its ability to be electrospun $^{44,46-48}$. Solvents that have been used frequently for dissolving and electro-spinning lignin fibres include dimethyl formamide and dimethyacetamide $2,24,26$.

This paper reports on the development of a method for electro-spinning a lignin/lignin blend, without using any additives. Lignin was fractionated using acetone and ethanol. The fractionated lignins, with different molecular weights, were dissolved in a 2:1 mixture of acetone and dimethyl sulfoxide prior to electro-spinning. The electros-spun fibres were thermo-oxidised, carbonised and characterised. The carbonised fibres were void-free, unfused and they had a circular cross-section. The fibres were characterised and compared with data reported in literature.

\section{Methods}


Prior to solvent fractionation, the softwood Kraft (BioChoice ${ }^{\circledR}$ ) lignin was dried in a vacuum oven at $80^{\circ} \mathrm{C}$ for $6 \mathrm{~h}$ under a reduced pressure of 1 bar to remove moisture and low-molecular weight volatiles. The pre-dried lignin was refluxed with the desired solvent (acetone or ethanol) for $6 \mathrm{~h}$ under constant agitation by bubbling argon gas at $30 \mathrm{~mL} \mathrm{~min}^{-1}$. The temperature of the solution was maintained at $56^{\circ} \mathrm{C}$ and $75^{\circ} \mathrm{C}$ for acetone and ethanol, respectively. The lignin-to-solvent ratio was maintained at $1 \mathrm{~g} \mathrm{per} 15 \mathrm{~mL}$. After refluxing, the solution was cooled to room temperature and filtered under reduced pressure. The solvent from the soluble lignin fraction was evaporated using a rotary evaporator under reduced pressure. The fractionated lignin including the soluble and the insoluble fractions were dried in a vacuum oven at $80^{\circ} \mathrm{C}$ for 6 hours and stored in air-tight container until required.

\section{Ash content of fractionated lignins}

The ash content in the pre-dried (moisture-free) lignins was determined using the following procedure. The procedure involved preheating alumina crucibles with lids to $525^{\circ} \mathrm{C}$ for 60 minutes and cooling them in a desiccator. Approximately 1 gram of lignin was transferred to the pre-dried and pre-weighed crucibles. Alumina lids were placed on the crucibles and they were positioned in a muffle furnace and heated from ambient temperature to $525^{\circ} \mathrm{C}$ to carbonise the lignin samples without causing it to ignite. Once the samples had charred, the lid was removed to oxidise lignin samples at $525^{\circ} \mathrm{C}$ for 4 hours. Upon cooling to room temperature, it was observed that samples had been converted from a black char to white powdery ash. The mass was recorded to the nearest $0.001 \mathrm{~g}$ using an analytical balance and the ash content was determined.

\section{Preparation of lignin solution for electro-spinning}

Solutions of fractionated acetone-soluble (ASL) and ethanol-soluble (ESL) lignin was made using a 2:1 (v/v) ratio of acetone and DMSO. A concentration of $52.8 \mathrm{wt} \%$ lignin was identified as an optimum total polymer concentration for electro-spinning (see supplementary Table S3 and Figure S5). The ASL concentration was kept at 95 wt \% with ESL making up the remainder. The solution was homogenised in a nitrogen atmosphere using a magnetic stirrer for $6 \mathrm{~h}$ and then stored in an airtight container until required.

\section{Electro-spinning of lignin solutions}

The electro-spinning of lignin solutions was carried out using a custom-built electro-spinner consisting of a disposable syringe and needle assembly (Teflon tube with Luer lock adapter, Cole Parmer), a controllable feed liquid dispenser (AL1010, World Precision Instruments) and a flat-tip needle of $25 \mathrm{G}$ (0.254 mm diameter, Adhesive Dispensing). A schematic illustration of the electro-spinning unit that was used to produce lignin fibres is shown in Figure 1. The needle was connected to the positive terminal of a high-voltage power supply (Laboratory bench power supply, Genvolt). The electro-spun fibres were collected on an aluminium foil placed on top of a grounded copper plate $(10 \times 10 \times 0.5 \mathrm{~cm})$. The distance from the tip of the needle to the collector plate was kept at $12 \mathrm{~cm}$ and the applied voltage was $12 \mathrm{kV}$. The polymer solution was dispensed at $0.1 \mu \mathrm{l} \mathrm{min}{ }^{-1}$. The temperature of the chamber was maintained between $25-30{ }^{\circ} \mathrm{C}$ with a relative humidity of $30-35 \%$. The electro-spinning operation was carried for 3 min.

\section{Thermo-stabilisation and carbonisation of lignin electro-spun fibres}

Prior to thermo-stabilisation, the electro-spun ASL-ESL lignin fibres were dried in vacuum oven at $140^{\circ} \mathrm{C}$ for $6 \mathrm{~h}$ to remove excess solvent from the electro-spun fibres. The pre-dried lignin fibres were transferred into a tube furnace (Pyrotherm) in a graphite crucible and heated to $100^{\circ} \mathrm{C}$ and held for $1 \mathrm{~h}$. The fibres were then heated to $150^{\circ} \mathrm{C}$, held for $1 \mathrm{~h}$ followed by heating to a final temperature of $250^{\circ} \mathrm{C}$ where they were held for another $1 \mathrm{~h}$. During the thermo-stabilisation step, a heating rate of $0.5 \mathrm{~K} \mathrm{~min}^{-1}$ was used under an air gas flow of $50 \mathrm{~mL} \mathrm{~min}{ }^{-1}$.

The thermo-stabilised ASL-ESL lignin fibres at $250^{\circ} \mathrm{C}$ were carbonised at $1500^{\circ} \mathrm{C}$. These samples were heated at $5 \mathrm{~K} \mathrm{~min}^{-1}$ under a nitrogen flow of $50 \mathrm{~mL} \mathrm{~min}{ }^{-1}$. The fibres were held isothermally at each temperature for one hour before cooling to room temperature. The sample morphology was characterised using SEM.

\section{Fibre morphology}

A TM3030 PLUS (Hitachi, Japan) SEM was used to characterise the surface and cross-section morphology of the lignin samples that were carbonised at $1000^{\circ} \mathrm{C}, 1200^{\circ} \mathrm{C}$ and $1500^{\circ} \mathrm{C}$. The SEM was operated with an acceleration voltage of $15 \mathrm{kV}$. The sample was mounted on SEM stub using an adhesive carbon tape and coated with Au/Pd for 3 mins using a current of $25 \mathrm{~mA}$ and a vacuum of 1 mTorr. 
The fibre diameter distribution of the lignin fibres, before and after carbonisation, was acquired using ImageJ analysis software. Three representative micrographs at a magnification of 2500 were selected for each sample and the diameter distribution was determined using one hundred individual measurements for each image.

\section{Electrical conductivity}

The electrical properties of the carbonised electro-spun lignin fibres were measured using a 4-point probe of RM3000 (Jandel Engineering Limited). Prior to measuring the electrical resistivity, the equipment was calibrated using a Jandel resistivity standard (Serial no. 74452, Jandel Engineering Limited). The carbonised lignin fibre with a width of $0.5 \mathrm{~cm}$ were mounted on a clean glass slide. The sheet or surface resistance of fibres that were carbonised at $1000^{\circ} \mathrm{C}, 1200^{\circ} \mathrm{C}$ and $1500^{\circ} \mathrm{C}$ was measured. The sample thickness of electro-spun carbonised mat was averaged from five individual measurements. The spacing or distance between the probes was set at $0.1 \mathrm{~cm}$ and the sample measurements were carried out at $24-25^{\circ} \mathrm{C}$ and with a relative humidity of $38-40 \%$. Five measurements of the surface resistance $(R)$ were made at different locations on the samples. The resistivity $(\Omega-\mathrm{cm})$ using four-point probe method can be measured according to the Equation 1:

$$
\rho=\frac{R}{L} A
$$

\section{Equation 149,50}

where $\rho$ is the resistivity and $L$ is the distance between the probes $(0.1 \mathrm{~cm})$ and $R$ is the electrical resistance; $A$ is the cross-sectional area of the sample.

\section{Raman spectroscopy}

An inVia confocal Raman Microscopy (Renishaw, UK) equipped with a $488 \mathrm{~nm}$ laser diode was used to observe the graphitic structure of the carbonised electro-spun fibres. The samples were mounted on the glass microslide. Raman spectra were acquired over a spectral range of $320-3200 \mathrm{~cm}^{-1}$ using 100 scans per sample at $10 \%$ laser power. The band intensities including the peak area (A) and the peak height (I) were determined. The ratio of intensities of $D$ to $G$ are represented by $I_{D} / I_{G}$ whilst $A_{D} / A_{G}$ shows the ratio of areas. ${ }^{51,52}$

\section{Results And Discussion}

The effect of treating lignin with acetone and ethanol on the solubility, yield and ash content is presented in Table 1. It was found to be partially soluble in acetone and ethanol. The highest yield attained was with acetone. Approximately $56 \%$ was recovered as the soluble fraction. As seen in Table 1, the ash content for the soluble fraction were in the range $0.1-0.11 \%$ whereas that for the as-received lignin was $1.24 \%$. This shows that solvent fractionation can reduce the inorganic impurities as inferred by the ash content in the soluble fractions. The ash content for the insoluble lignin fraction was 1.99-2.17\%. The conventional approach to remove the inorganic content in lignin is to treat it with acids. This was carried out with the as-received lignin and the ash content was $0.34 \%$.

Table 1

Solvent fractionation yields with their respective ash contents for each lignin fraction.

\begin{tabular}{|llll|}
\hline Solvents & Fractionation Yields (\%) & $\begin{array}{l}\text { Ash Content } \\
\text { (\%) }\end{array}$ & \\
\cline { 3 - 4 } & & Soluble Fraction & Insoluble Fraction \\
\hline Acetone & 56 & 0.10 & 2.17 \\
\hline Ethanol & 38 & 0.11 & 1.99 \\
\hline
\end{tabular}

\section{Electro-spinning of ASL-ESL}

The fibres were spun on to a flat plate collector and a schematic illustration of electro-spinning setup was shown in the experimental method section. A macroscopic image of the deposition area of the electro-spun lignin is shown in Fig. 2a-f. Pale brownish fibres were deposited over a diameter of $3-4 \mathrm{~cm}$. The fibres within this area were orientated randomly. Figure $2 b-f$ show representative 
micrographs for the $52.8 \%$ total polymer concentration where the fibres are unfused and orientated randomly. Figure 2e-f shows highmagnification SEM micrographs for the transverse section where it can be seen the fibres are void-free and with a smooth surface.

Electro-spinning of fractionated lignin without any additives was successfully demonstrated for the first time (Fig. 2). This is significant as Softwood Kraft lignin was found to be unsuitable for the production of carbon fibres and for use in biorefineries due to its higher content of impurities ${ }^{18,19}$. The electro-spun ASL-ESL lignin fibres were dried in a vacuum oven at $140^{\circ} \mathrm{C}$ and then subsequently thermo-stabilised in air at $250^{\circ} \mathrm{C}$. The thermo-stabilised fibres maintained their form and structural shape. The change in structural and physical properties during thermo-stabilisation will be discussed in subsequent publication. The thermo-stabilised lignin fibres were carbonised in a tube furnace at $1000^{\circ} \mathrm{C}, 1200^{\circ} \mathrm{C}$ and $1500^{\circ} \mathrm{C}$. The colour change observed before and after the specified heat-treatment of the electro-spun lignin fibres is shown in Fig. 3. The as-spun fibres turn from pale yellow/brown to dark brown and eventually to black upon carbonisation.

SEM micrographs of the carbonised lignin fibres (ASL-ESL) at $1000^{\circ} \mathrm{C}, 1200^{\circ} \mathrm{C}$ and $1500^{\circ} \mathrm{C}$ are shown in Fig. 4 (a-f). The surface morphology of the fibres is seen to be smooth, circular in cross-section and unfused. This demonstrates conclusively that electro-spun lignin fibres can be obtained without the use of any processing aids or synthetic polymer blends. In other words, this represents the production of electro-spun fibres using $100 \%$ lignin.

Transverse section of the electro-spun (ASL-ESL) lignin fibres that were carbonised at $1000^{\circ} \mathrm{C}, 1200^{\circ} \mathrm{C}$ and $1500^{\circ} \mathrm{C}$ is shown in Fig. 5 . These micrographs demonstrate that the fibres are not fused and that their cross-section is circular. Figure 5 (a-c) and Fig. 6 (a-f) show that the fibre diameter decreases as a function of the carbonisation temperature. This is expected due to shrinkage and mass-loss during carbonisation. Figure 5 (a-c) show the presence of fractured fibres. This was possibly caused when the electro-spun preform was fractured in liquid nitrogen to obtain transverse sections. However, fracture caused by fibre shrinkage during carbonised cannot be ruled out.

\section{Fibre diameter distribution}

The fibre diameter distribution for the electro-spun ASL-ESL lignin fibres in the as-spun and after specified heat treatments are shown in Fig. 6 (a-f). The data sets are represented as histogram plots with an overlaid normal distribution curve. The diameters for the electro-spun samples represented in Fig. 6 are as follows: (a) as-spun 0.6-2.8 $\mu \mathrm{m}$; (b) vacuum-dried 0.6-2.8 $\mu$ m; (c) thermo-stabilised lignin fibre in air at $250^{\circ} \mathrm{C}: 0.6-2.4 \mu \mathrm{m}$; (d) carbonised lignin fibres in nitrogen at $1000^{\circ} \mathrm{C} 0.6-1.4 \mu \mathrm{m}$; (e) $1200^{\circ} \mathrm{C}: 0.6-1.4 \mu \mathrm{m}$ and (f) $1500^{\circ} \mathrm{C}: 0.6-1.2 \mu \mathrm{m}$. The as-spun and vacuum dried lignin fibres showed the widest distributions ranging between $0.6-2.8 \mu \mathrm{m}$. There is a noticeable change in diameter for the air thermo-stabilised lignin fibre diameter at $250^{\circ} \mathrm{C}$. The most significant change in the diameter distribution for the electro-spun fibres was observed during the carbonisation stage. The narrowest diameter distribution $(0.4-1.2 \mu \mathrm{m})$ was obtained for the lignin fibres that were carbonised at $1500^{\circ} \mathrm{C}$.

\section{Electrical conductivity of electro-spun ASL-ESL carbonised lignin fibres}

The electrical properties of the carbonised lignin samples are shown in Table 2. The electrical properties of the solid carbonised lignin fibres are important for determining their suitability for energy storage applications such as electrodes for dye-sensitised solar cells, batteries, fuel cells, capacitors and super capacitors. As seen in Table 2, the electrical conductivity of the lignin fibres increased with carbonisation temperature from $1000^{\circ} \mathrm{C}$ to $1200^{\circ} \mathrm{C}$ and $1500^{\circ} \mathrm{C}$. The lignin fibres that were carbonised at $1500^{\circ} \mathrm{C}$ show electrical conductivity comparable to those reported in literature for softwood Kraft lignin $\left(230 \mathrm{~S} \mathrm{~m}^{-1}\right)^{2,52}$. This suggests that the carbon fibre produced from $100 \%$ lignin, without any binder as in the current case, are of comparable quality to those reported in literature. 
Table 2

Electrical properties of the carbonised ASL-ESL

lignin fibres that were carbonised in nitrogen at $1000^{\circ} \mathrm{C}, 1200^{\circ} \mathrm{C}$ and $1500^{\circ} \mathrm{C}$ for $1 \mathrm{~h}$.

\begin{tabular}{|lll|}
\hline Samples & $\begin{array}{l}\text { Resistivity } \\
(\boldsymbol{\Omega} \mathbf{~})\end{array}$ & $\begin{array}{l}\text { Electrical conductivity } \\
\left(\mathbf{S ~ m}^{-1} \mathbf{)}\right.\end{array}$ \\
\hline $1000^{\circ} \mathrm{C}$ & $0.96 \pm 0.14$ & $105.64 \pm 14.86$ \\
\hline $1200^{\circ} \mathrm{C}$ & $0.51 \pm 0.05$ & $197.18 \pm 20.40$ \\
\hline $1500^{\circ} \mathrm{C}$ & $0.49 \pm 0.06$ & $205.80 \pm 24.33$ \\
\hline
\end{tabular}

\section{Raman spectroscopy of electro-spun ASL-ESL carbonised lignin fibres}

Raman spectroscopy was used to evaluate the structural changes in the lignin samples as a result of carbonisation. Raman spectra of the lignin fibres that were carbonised at $1000^{\circ} \mathrm{C}, 1200^{\circ} \mathrm{C}$ and $1500^{\circ} \mathrm{C}$ are shown in Fig. 7. There are two distinct peaks present in the Raman spectra for the carbonised lignin fibres. These characteristic peaks correspond to $D$ and G-bands which are typical of lignin and PAN-based carbon fibres. The D-band which appears at $\sim 1350 \mathrm{~cm}^{-1}$ is attributed to the breathing modes of carbon atoms in aromatic rings. The G-band which appears at $\sim 1600 \mathrm{~cm}^{-1}$ is ascribed to the in plane stretching of $s p^{2}$ carbon hybridized bonds $(C=C)$ in the aromatic rings ${ }^{2,51}$. Therefore, in general, the D-band indicates disorder or defects in the graphitic structure and the G-band represents $s p^{2}$ ordered graphitic carbon.

The small peak between $1000-1200 \mathrm{~cm}^{-1}$ could be attributed to $s p^{3}$ hybridised carbon ${ }^{53}$. The emergence of significant new peaks at approximately 2700 and $2900 \mathrm{~cm}^{-1}$ is observed as the carbonisation temperature was increased from $1000^{\circ} \mathrm{C}$ to $1500^{\circ} \mathrm{C}$. This band is a result of second order resonance from the $D$-band and it is normally referred to as $2 \mathrm{D}$ band. This $2 \mathrm{D}$ band is a characteristic feature of increased stacking in the layered graphitic sheets ${ }^{4,54}$.

The relative positions of the $D$ and G-bands in the Raman spectra with an analysis of the ratios of two peaks is shown in Table 3 . The intensity of the $D$ and G-bands increases with the processing temperature. The intensity $\left(I_{D} / I_{G}\right)$ and area $\left(A_{D} / A_{G}\right)$ ratios of the two bands increase with temperature. This suggests that more disorder is introduced in the graphitic structure with increasing carbonisation temperature from $1000^{\circ} \mathrm{C}$ to $1500^{\circ} \mathrm{C}$. This is said to indicate the existence of turbostratic graphite which is thought to be composed of highly condensed aromatic structure between the amorphous carbon and graphite ${ }^{51,55}$. The increase in the ratio of $I_{D} / I_{G}$ is directly in contrast to carbon fibres made from PAN where this ratio is seen to decline with the increasing carbonisation temperature ${ }^{56-58}$. However, these findings are in complete agreement with reported Raman results on the carbon fibres obtained from lignin ${ }^{4,20}$. Moreover, it is reported that the higher molecular weight of lignin enhances the graphitic structure and mechanical performance ${ }^{59}$.

Table 3

Analysis of the position of the D and G-band in the Raman spectra for the carbonised lignin fibres and the full width at high maximum (FWHM) for these bands along with their intensity and area ratios.

\begin{tabular}{|c|c|c|c|c|c|c|}
\hline \multirow[t]{2}{*}{ Sample } & \multirow{2}{*}{$\begin{array}{l}\text { D-band } \\
\left(\mathrm{cm}^{-1}\right)\end{array}$} & \multirow{2}{*}{$\begin{array}{l}\text { G-band } \\
\left(\mathrm{cm}^{-1}\right)\end{array}$} & \multicolumn{2}{|c|}{ Width (FWHM) $\left(\mathrm{cm}^{-1}\right)$} & \multirow[t]{2}{*}{$I_{D} / I_{G}$} & \multirow[t]{2}{*}{$A_{D} / A_{C}$} \\
\hline & & & D-band & G-band & & \\
\hline $1000^{\circ} \mathrm{C}$ & 1352.91 & 1597.02 & 164.52 & 135.18 & 0.82 & 0.96 \\
\hline $1200^{\circ} \mathrm{C}$ & 1348.61 & 1597.02 & 146.19 & 89.85 & 0.91 & 1.07 \\
\hline $1500^{\circ} \mathrm{C}$ & 1342.88 & 1583.11 & 107.59 & 77.97 & 1.04 & 1.13 \\
\hline
\end{tabular}

The FWHM of the D and G- bands is attributed to the degree of structural disorder. It is seen in Table 3 that the D and G-bands experience a decrease in the FWHM values, but G-band shows more narrower line width as the carbonisation temperature is increased. This indicates the lignin sample carbonised at higher temperature start to attain a crystallite graphitic structure ${ }^{4,60}$.

\section{Conclusions}


The solvent fractionation with acetone and ethanol lead to the reduction in ash content (1.24 to $0.1 \%)$, average molecular weight (7367 to $5370 \mathrm{~g} / \mathrm{mol})$ and glass transition temperature $\left(155\right.$ to $\left.134^{\circ} \mathrm{C}\right)$ as determined using molecular weight distribution curves and differential scanning calorimetry (shown in supplementary Figure S2-S5 and Table S2). The electrospinning of 100\% lignin without any additives was demonstrated successfully for the first time by using non-toxic green solvents (acetone/DMSO). The procedures reported in this study will enable the sustainable production of carbon fibres using lignin and green solvents. The electro-spun and carbonised lignin fibres were void-free with a circular cross-section. The electrical conductivity was comparable to those reported in the literature. An increase in the carbonisation temperature lead to an increase in the graphitic structure as indicated by a narrower FWHM for the Gband in the Raman spectra. The diameter of the lignin fibre was found to reduce with the increase in carbonisation temperature. The mean fibre diameter observed after carbonisation at $1500^{\circ} \mathrm{C}$ was $0.8 \mu \mathrm{m} \pm 0.4$.

\section{Declarations}

\section{Acknowledgments}

IK acknowledges funding from the Engineering and Physical Research Council for a PhD studentship. The authors also acknowledge funding from the European Union's Seventh Framework Program (FP7/2007-2013) under the Agreement No. GA604248.

The authors would like to thank Dr Venkata Machavaram, Dr Surya Pandita, Siheng Shao, Tao Ma, Frank Biddlestone, Professor Hanshan Dong and Professor Costas Charitidis for their help and assistance during the course of this research project.

\section{Author contributions}

The manuscript was written through contributions of all authors. All authors have given approval to the final version of the manuscript.

\section{Competing interest}

The authors declare no competing request.

\section{References}

1. Dallmeyer, I., Ko, F. \& Kadla, J. F. Correlation of Elongational Fluid Properties to Fiber Diameter in Electrospinning of Softwood Kraft Lignin Solutions. Ind. Eng. Chem. Res. 53, 2697-2705 https://doi.org/10.1021/ie403724y (2014).

2. Dallmeyer, I., Lin, L. T., Li, Y., Ko, F. \& Kadla, J. F. Preparation and Characterization of Interconnected, Kraft Lignin-Based Carbon Fibrous Materials by Electrospinning. Macromolecular Materials and Engineering. 299, 540-551 https://doi.org/10.1002/mame.201300148 (2014).

3. Ago, M., Okajima, K., Jakes, J. E., Park, S. \& Rojas, O. J. Lignin-Based Electrospun Nanofibers Reinforced with Cellulose Nanocrystals. Biomacromolecules. 13, 918-926 https://doi.org/10.1021/bm201828g (2012).

4. Bengtsson, A. et al. Carbon Fibers from Lignin-Cellulose Precursors: Effect of Carbonization Conditions. ACS Sustainable Chemistry \& Engineering. 8, 6826-6833 https://doi.org/10.1021/acssuschemeng.0c01734 (2020).

5. Bengtsson, A. et al. Improved yield of carbon fibres from cellulose and kraft lignin. (2018).

6. Baker, D. A. \& Rials, T. G. Recent advances in low-cost carbon fiber manufacture from lignin. Journal of Applied Polymer Science. 130, 713-728 https://doi.org/10.1002/app.39273 (2013).

7. Norberg, l., Nordström, Y., Drougge, R., Gellerstedt, G. \& Sjöholm, E. A new method for stabilizing softwood kraft lignin fibers for carbon fiber production. Journal of Applied Polymer Science. 128, 3824-3830 https://doi.org/10.1002/app.38588 (2013).

8. Alekhina, M., Ershova, O., Ebert, A., Heikkinen, S. \& Sixta, H. Softwood kraft lignin for value-added applications: Fractionation and structural characterization. Industrial Crops and Products. 66, 220-228 https://doi.org/10.1016/j.indcrop.2014.12.021 (2015).

9. Demuner, I. F., Colodette, J. L., Demuner, A. J. \& Jardim, C. M. Biorefinery Review: Wide-Reaching Products Through Kraft Lignin. 2019 14, 39(2019).

10. Zakzeski, J., Bruijnincx, P. C. A., Jongerius, A. L. \& Weckhuysen, B. M. The Catalytic Valorization of Lignin for the Production of Renewable Chemicals. Chem. Rev. 110, 3552-3599 https://doi.org/10.1021/cr900354u (2010).

11. Kai, D., Jiang, S., Low, Z. W. \& Loh, X. J. Engineering highly stretchable lignin-based electrospun nanofibers for potential biomedical applications. Journal of Materials Chemistry B. 3, 6194-6204 https://doi.org/10.1039/C5TB00765H (2015).

Page $7 / 14$ 
12. Kubo, S. \& Kadla, J. F. Lignin-based Carbon Fibers: Effect of Synthetic Polymer Blending on Fiber Properties. Journal of Polymers and the Environment. 13, 97-105 https://doi.org/10.1007/s10924-005-2941-0 (2005).

13. Seydibeyoğlu, M. A. \& Novel Partially Biobased PAN-Lignin Blend as a Potential Carbon Fiber Precursor. Journal of biomedicine \& biotechnology 2012, 598324, doi:10.1155/2012/598324 (2012).

14. Hodásová, Ä., Jablonsky, M., Andrea, S. \& Haz, A. Lignin, potential products and their market value. Wood research. $60,973-986$ (2015).

15. Frank, E., Steudle, L. M., Ingildeev, D., Spörl, J. M. \& Buchmeiser, M. R. Carbon Fibers: Precursor Systems, Processing, Structure, and Properties. Angew. Chem. Int. Ed. 53, 5262-5298 https://doi.org/10.1002/anie.201306129 (2014).

16. Liu, H. et al. Lignin/Polyacrylonitrile Carbon Fibers: The Effect of Fractionation and Purification on Properties of Derived Carbon Fibers. ACS Sustainable Chemistry \& Engineering. 6, 8554-8562 https://doi.org/10.1021/acssuschemeng.8b00868 (2018).

17. Hu, Z., Du, X., Liu, J., Chang, H. \& Jameel, H. Structural Characterization of Pine Kraft Lignin: BioChoice Lignin vs Indulin AT. Journal of Wood Chemistry and Technology. 36, 432-446 https://doi.org/10.1080/02773813.2016.1214732 (2016).

18. Lu, Y. et al. Structural Characterization of Lignin and Its Degradation Products with Spectroscopic Methods. Journal of Spectroscopy 2017, 15, doi:10.1155/2017/8951658 (2017).

19. Ghosh, T., Ngo, T. D., Kumar, A., Ayranci, C. \& Tang, T. Cleaning carbohydrate impurities from lignin using Pseudomonas fluorescens. Green Chem. 21, 1648-1659 https://doi.org/10.1039/C8GC03341B (2019).

20. Steudle, L. et al. Carbon Fibers Prepared from Melt Spun Peracylated Softwood Lignin: an Integrated Approach. Vol. 302 (2017).

21. Fang, W., Yang, S., Wang, X. L., Yuan, T. Q. \& Sun, R. C. Manufacture and application of lignin-based carbon fibers (LCFs) and lignin-based carbon nanofibers (LCNFs). Green Chem. 19, 1794-1827 https://doi.org/10.1039/C6GC03206K (2017).

22. Ding, R., Wu, H., Thunga, M., Bowler, N. \& Kessler, M. R. Processing and characterization of low-cost electrospun carbon fibers from organosolv lignin/polyacrylonitrile blends. Carbon. 100, 126-136 https://doi.org/10.1016/j.carbon.2015.12.078 (2016).

23. Liu, H. C. et al. Structure, and Properties of Lignin- and CNT-Incorporated Polyacrylonitrile-Based Carbon Fibers. ACS Sustainable Chemistry \& Engineering. 3, 1943-1954 https://doi.org/10.1021/acssuschemeng.5b00562 (2015).

24. Cho, M., Karaaslan, M. A., Renneckar, S. \& Ko, F. Enhancement of the mechanical properties of electrospun lignin-based nanofibers by heat treatment. Journal of Materials Science. 52, 9602-9614 https://doi.org/10.1007/s10853-017-1160-0 (2017).

25. Cho, M., Karaaslan, M., Chowdhury, S., Ko, F. \& Renneckar, S. Skipping Oxidative Thermal Stabilization for Lignin-Based Carbon Nanofibers. ACS Sustainable Chemistry \& Engineering. 6, 6434-6444 https://doi.org/10.1021/acssuschemeng.8b00209 (2018).

26. Dallmeyer, I., Ko, F. \& Kadla, F. J. Electrospinning of Technical Lignins for the Production of Fibrous Networks. Vol. 30 (2010).

27. Huang, Z. M., Zhang, Y. Z., Kotaki, M. \& Ramakrishna, S. A review on polymer nanofibers by electrospinning and their applications in nanocomposites. Composites Science and Technology. 63, 2223-2253 https://doi.org/10.1016/S0266-3538(03)00178-7 (2003).

28. Zhang, Y., Lim, C. T., Ramakrishna, S. \& Huang, Z. M. Recent development of polymer nanofibers for biomedical and biotechnological applications. Journal of Materials Science: Materials in Medicine. 16, 933-946 https://doi.org/10.1007/s10856005-4428-x (2005).

29. Hammel, E. et al. Carbon nanofibers for composite applications. Carbon. 42, 1153-1158 https://doi.org/10.1016/j.carbon.2003.12.043 (2004).

30. Fan, Z. et al. Asymmetric Supercapacitors Based on Graphene/MnO2 and Activated Carbon Nanofiber Electrodes with High Power and Energy Density. Adv. Funct. Mater. 21, 2366-2375 https://doi.org/10.1002/adfm.201100058 (2011).

31. Khandan, A. et al. Electrospun Polycaprolactone/lignin-based Nanocomposite as a Novel Tissue Scaffold for Biomedical Applications. J Med Sign Sens. 7, https://doi.org/10.4103/jmss.JMSS_11_17 (2017).

32. Salami, M. A. et al. Electrospun Polycaprolactone/lignin-based Nanocomposite as a Novel Tissue Scaffold for Biomedical Applications. Journal of medical signals and sensors. 7, 228-238 (2017).

33. Hsu, Y. H., Chan, C. H. \& Tang, W. C. Alignment of Multiple Electrospun Piezoelectric Fiber Bundles Across Serrated Gaps at an Incline: A Method to Generate Textile Strain Sensors. Sci. Rep. 7, 15436 https://doi.org/10.1038/s41598-017-15698-7 (2017).

34. Tenhaeff, E., Rios, W., More, O. \& McGuire, A. K. \& M. Highly Robust Lithium Ion Battery Anodes from Lignin: An Abundant, Renewable, and Low-Cost Material. Vol. 24 (2014). 
35. Zhang, H. et al. Design advanced carbon materials from lignin-based interpenetrating polymer networks for high performance sodium-ion batteries. Chem. Eng. J. 341, 280-288 https://doi.org/10.1016/j.cej.2018.02.016 (2018).

36. Lima, R. B. et al. Direct lignin fuel cell for power generation. RSC Advances. 3, 5083-5089 https://doi.org/10.1039/C3RA23418E (2013).

37. You, X., Duan, J., Koda, K., Yamada, T. \& Uraki, Y. Preparation of electric double layer capacitors (EDLCs) from two types of electrospun lignin fibers. Vol. 70 (2016).

38. Zhao, Y. et al. Flexible lignin-derived electrospun carbon nanofiber mats as a highly efficient and binder-free counter electrode for dye-sensitized solar cells. Journal of Materials Science. 53, 7637-7647 https://doi.org/10.1007/s10853-018-2059-0 (2018).

39. Nirmale, T. C., Kale, B. B. \& Varma, A. J. A review on cellulose and lignin based binders and electrodes: Small steps towards a sustainable lithium ion battery. International Journal of Biological Macromolecules. 103, 1032-1043 https://doi.org/10.1016/j.jibiomac.2017.05.155 (2017).

40. Teng, N. Y., Dallmeyer, I. \& Kadla, J. F. Effect of Softwood Kraft Lignin Fractionation on the Dispersion of Multiwalled Carbon Nanotubes. Ind. Eng. Chem. Res. 52, 6311-6317 https://doi.org/10.1021/ie303261z (2013).

41. Ma, X., Kolla, P., Zhao, Y., Smirnova, A. L. \& Fong, H. Electrospun lignin-derived carbon nanofiber mats surface-decorated with MnO2 nanowhiskers as binder-free supercapacitor electrodes with high performance. Journal of Power Sources. 325, 541-548 https://doi.org/10.1016/j.jpowsour.2016.06.073 (2016).

42. Park, C. W., Youe, W. J., Han, S. Y., Yong, K. \& Lee, S. H. S. \& in Holzforschung Vol. 71 743(2017).

43. Schreiber, M., Vivekanandhan, S., Cooke, P., Mohanty, A. \& Misra, M. Electrospun green fibres from lignin and chitosan: A novel polycomplexation process for the production of lignin-based fibres. Journal of Materials Science. 49, https://doi.org/10.1007/s10853-014-8481-z (2014).

44. Kubo, S. \& Kadla, J. F. The Formation of Strong Intermolecular Interactions in Immiscible Blends of Poly(vinyl alcohol) (PVA) and Lignin. Biomacromolecules. 4, 561-567 https://doi.org/10.1021/bm025727p (2003).

45. Hosseinaei, O., Harper, P. D., Bozell, J. J. \& Rials, G. T. Improving Processing and Performance of Pure Lignin Carbon Fibers through Hardwood and Herbaceous Lignin Blends. International Journal of Molecular Sciences. 18, https://doi.org/10.3390/ijms18071410 (2017).

46. Schreiber, M., Vivekanandhan, S., Mohanty, A. \& Misra, M. A Study on the electrospinning behaviour and nanofibre morphology of anionically charged lignin. Advanced Materials Letters. 3, https://doi.org/10.5185/amlett.2012.icnano.336 (2012).

47. Kadla, J. F., Kubo, S., Venditti, R. A. \& Gilbert, R. D. Novel hollow core fibers prepared from lignin polypropylene blends. Journal of Applied Polymer Science. 85, 1353-1355 https://doi.org/10.1002/app.10640 (2002).

48. Fang, W., Yang, S., Yuan, T. Q., Charlton, A. \& Sun, R. C. Effects of Various Surfactants on Alkali Lignin Electrospinning Ability and Spun Fibers. Ind. Eng. Chem. Res. 56, 9551-9559 https://doi.org/10.1021/acs.iecr.7b02494 (2017).

49. Ghorbani, M. M. \& Taherian, R. in Electrical Conductivity in Polymer-Based Composites (eds Reza Taherian \& Ayesha Kausar) 365394(William Andrew Publishing, 2019).

50. Aslanzadeh, S., Ahvazi, B., Boluk, Y. \& Ayranci, C. Carbon Fiber Production from Electrospun Sulfur Free Softwood Lignin Precursors. Journal of Engineered Fibers and Fabrics. 12, 33-43 https://doi.org/10.1177/155892501701200405 (2017).

51. Zhang, X. et al. Carbon Nanostructure of Kraft Lignin Thermally Treated at 500 to $1000^{\circ} \mathrm{C}$. Materials. 10 , https://doi.org/10.3390/ma10080975 (2017).

52. Cho, M., Ko, F. \& Renneckar, S. Impact of Thermal Oxidative Stabilization on the Performance of Lignin-Based Carbon Nanofiber Mats. Vol. 4 (2019).

53. Major, I. et al. Graphitization of Miscanthus grass biocarbon enhanced by in situ generated FeCo nanoparticles. Green Chem. 20, 2269-2278 https://doi.org/10.1039/C7GC03457A (2018).

54. Tatarova, E. et al. Towards large-scale in free-standing graphene and N-graphene sheets. Sci. Rep. 7, 10175 https://doi.org/10.1038/s41598-017-10810-3 (2017).

55. Li, Y., Cui, D., Tong, Y. \& Xu, L. Study on structure and thermal stability properties of lignin during thermostabilization and carbonization. International Journal of Biological Macromolecules. 62, 663-669 https://doi.org/10.1016/j.ijbiomac.2013.09.040 (2013).

56. Kim, C. et al. Raman spectroscopic evaluation of polyacrylonitrile-based carbon nanofibers prepared by electrospinning. Journal of Raman Spectroscopy. 35, 928-933 https://doi.org/10.1002/jrs.1233 (2004).

Page 9/14 
57. Zhu, J. et al. Nitrogen-doped carbon nanofibers derived from polyacrylonitrile for use as anode material in sodium-ion batteries. Carbon. 94, 189-195 https://doi.org/10.1016/j.carbon.2015.06.076 (2015).

58. Lee, S. Structural Evolution of Polyacrylonitrile Fibers in Stabilization and Carbonization. Advances in Chemical Engineering and Science. 02, 275-282 https://doi.org/10.4236/aces.2012.22032 (2012).

59. Sagues, W. J. et al. Are lignin-derived carbon fibers graphitic enough? Green Chem. 21, 4253-4265 https://doi.org/10.1039/C9GC01806A (2019).

60. Snowdon, M. R., Mohanty, A. K. \& Misra, M. A. Study of Carbonized Lignin as an Alternative to Carbon Black. ACS Sustainable Chemistry \& Engineering. 2, 1257-1263 https://doi.org/10.1021/sc500086v (2014).

\section{Figures}

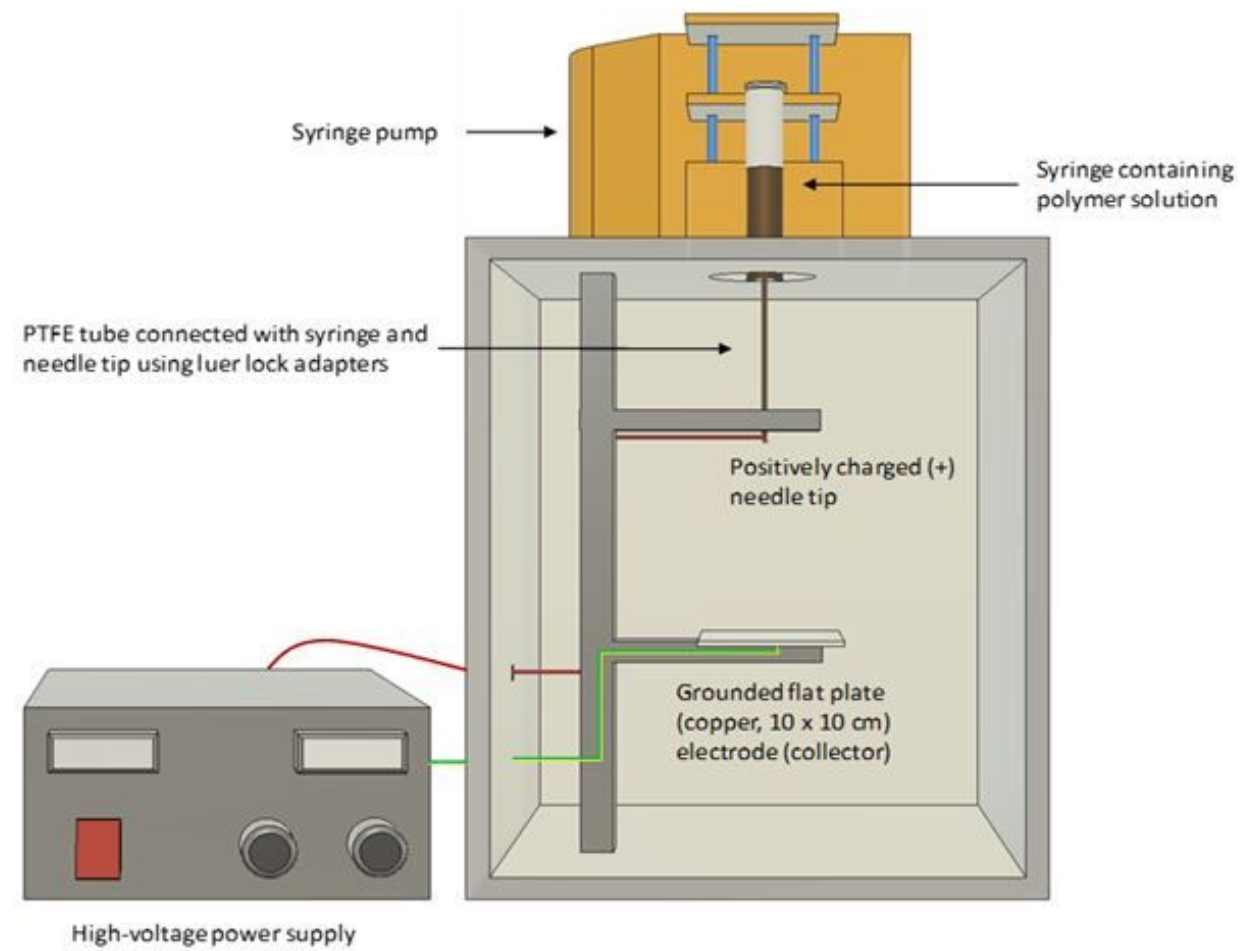

\section{Figure 1}

Schematic illustration of electro-spinning setup with a flat plate ground-electrode for collecting randomly oriented lignin fibres. 

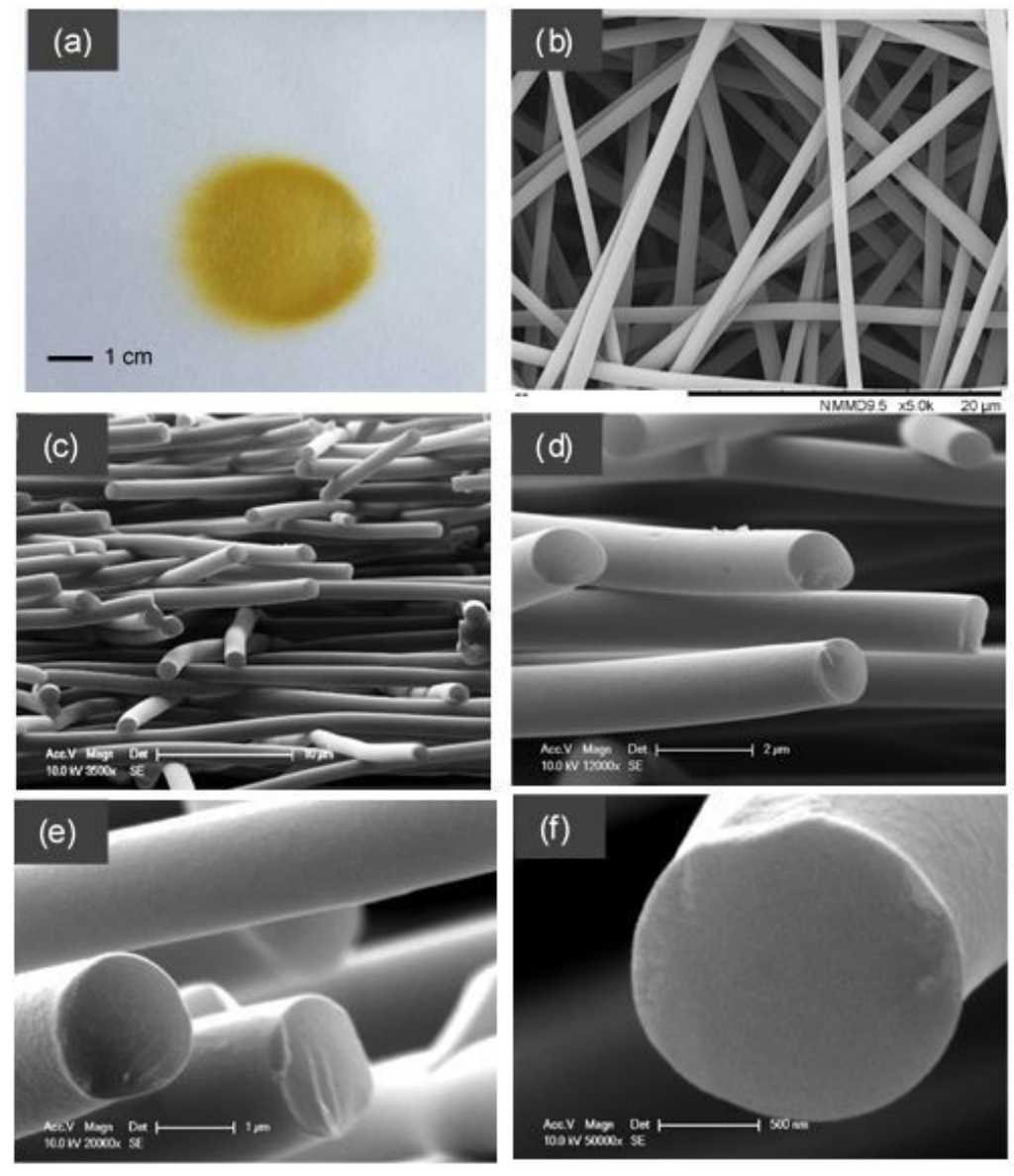

\section{Figure 2}

(a-f) Electro-spun lignin fibres using 95ASL-5ESL in acetone/DMSO: (a) macroscopic appearance of the deposition area (randomly oriented fibres); and (b-f) magnified SEM micrograph of fibres produced using the $52.8 \mathrm{wt} \%$ total polymer solution concentration.

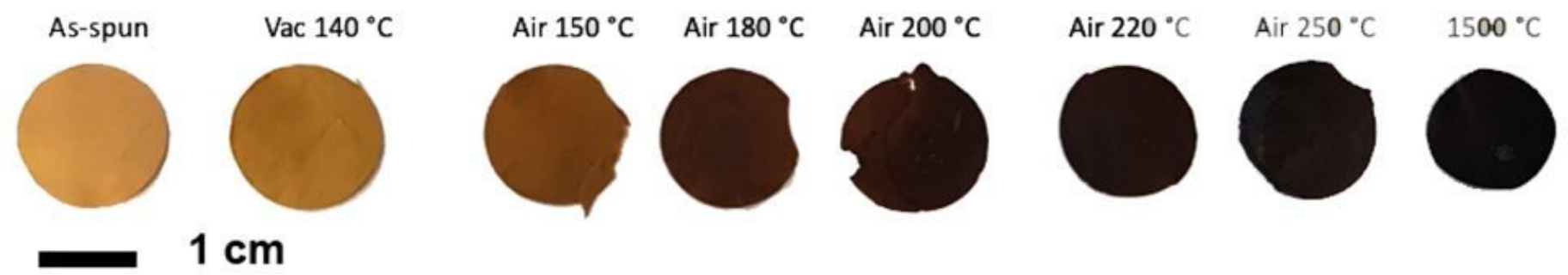

\section{Figure 3}

Colour changes in the electro-spun ASL-ESL lignin fibres before and after heat treatment at specified temperatures. 


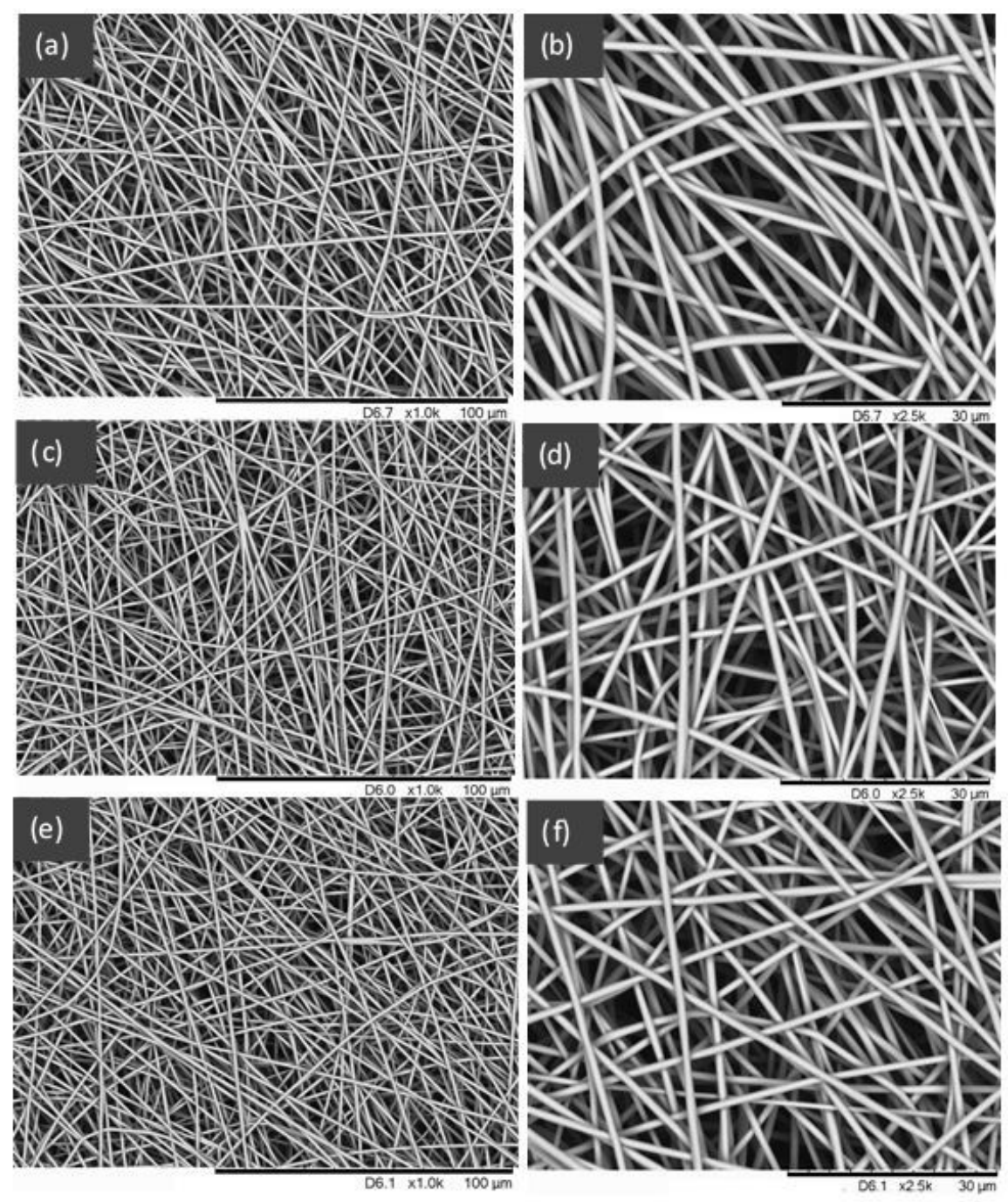

Figure 4

Electro-spun and carbonised (ASL-ESL) lignin fibres after carbonisation at $1000^{\circ} \mathrm{C}(\mathrm{a}, \mathrm{b}), 1200^{\circ} \mathrm{C}(\mathrm{c}, \mathrm{d})$ and $1500^{\circ} \mathrm{C}(\mathrm{e}, \mathrm{f})$ with magnifications of $x 1000$ and $\times 2500$.
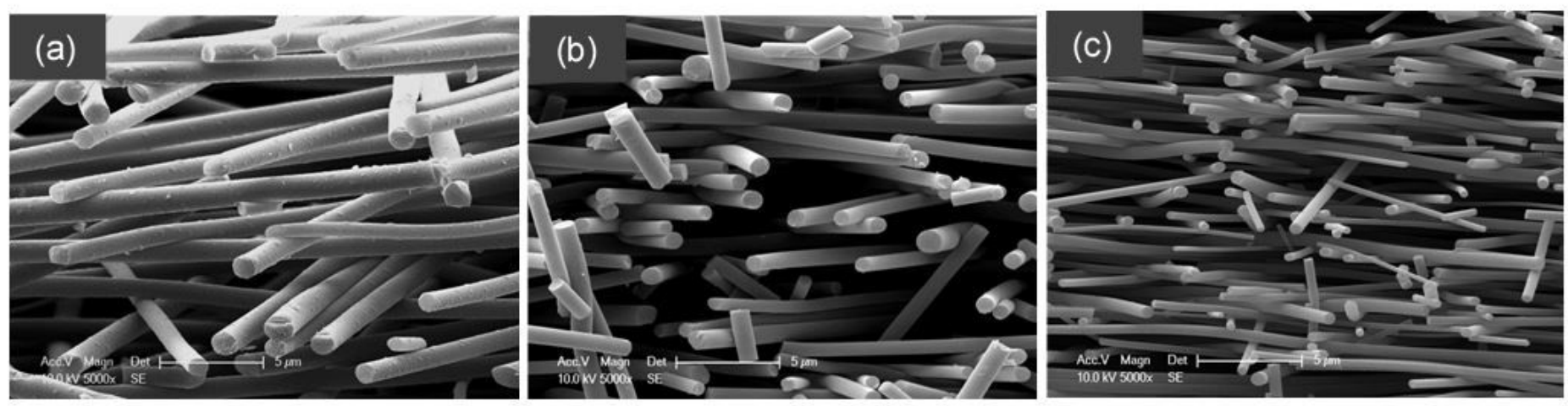

Figure 5

(a-c) Micrographs showing transverse sections of electro-spun (ASL-ESL) lignin fibres after carbonisation at $1000^{\circ} \mathrm{C}, 1200^{\circ} \mathrm{C}$ and $1500^{\circ} \mathrm{C}$ respectively. 

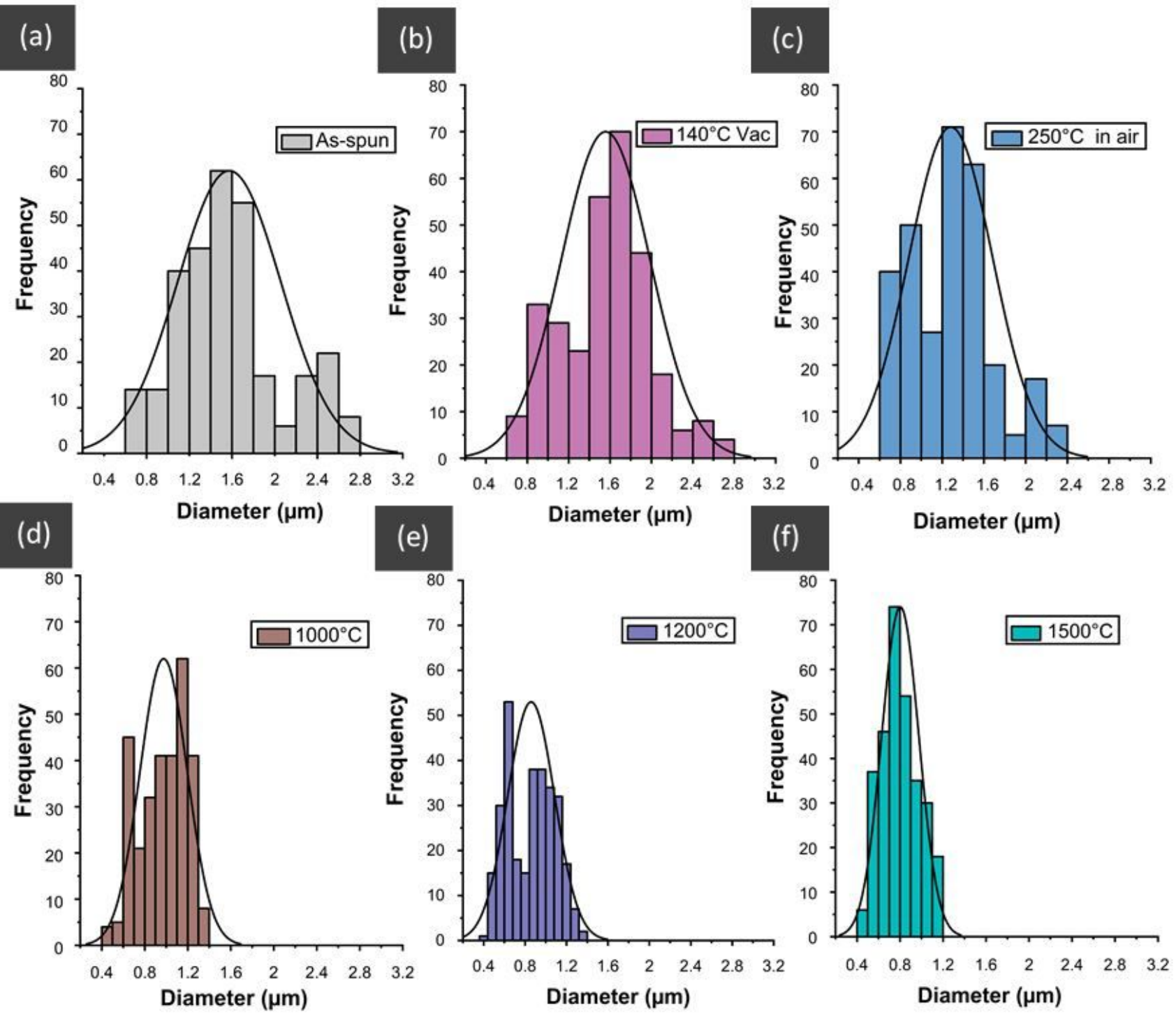

Figure 6

Histogram plots for the diameter distribution for the electro-spun (ASL-ESL) lignin fibres: as-spun (a), vacuum-heated at $140^{\circ} \mathrm{C}$ (b), thermo-oxidative stabilised at $250^{\circ} \mathrm{C}(\mathrm{c})$, and carbonised at $1000^{\circ} \mathrm{C}(\mathrm{d}), 1200^{\circ} \mathrm{C}(\mathrm{e})$ and $1500^{\circ} \mathrm{C}$ in nitrogen (f). The histograms have been overlaid with a normal diameter distribution curve for each data set. 


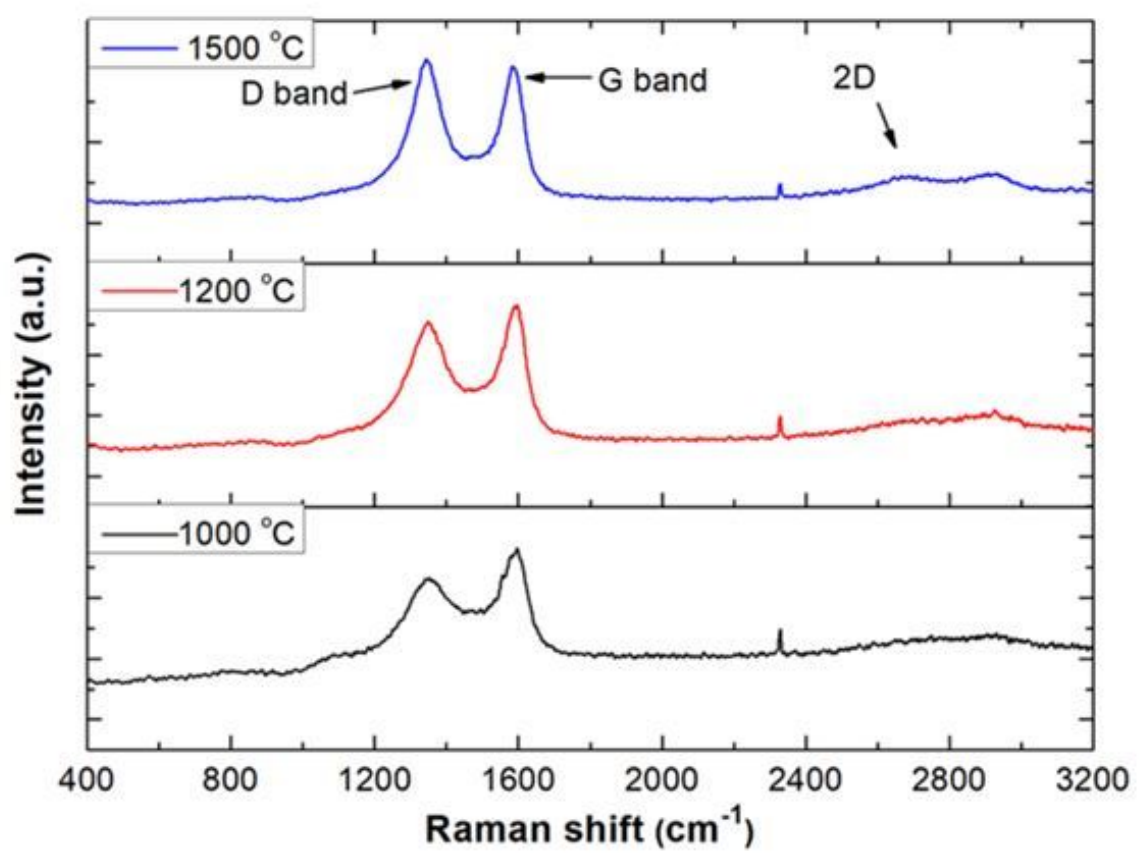

Figure 7

Raman spectra of electro-spun and randomly orientated lignin fibre mats that were carbonised at $1000^{\circ} \mathrm{C}, 1200^{\circ} \mathrm{C}$ and $1500^{\circ} \mathrm{C}$ in nitrogen for 1 hour.

\section{Supplementary Files}

This is a list of supplementary files associated with this preprint. Click to download.

- SupplementaryInformationImprovedProcedureforElectrospinningandCarbonisationofNeatSolventFractionSoftwoodKraftLignin.pdf 